\title{
Leszek Czerwonka
}

Uniwersytet Gdański

e-mail: leszczer@panda.bg.univ.gda.pl

\section{Jacek Jaworski}

Wyższa Szkoła Bankowa w Gdańsku

e-mail: jjaworski@wsb.gda.pl

\section{DETERMINANTY STRUKTURY \\ KAPITALU PRZEDSIECIORSTW. PRZEGLĄD LITERATURY}

\section{DETERMINANTS OF ENTERPRISES' \\ CAPITAL STRUCTURE. LITERATURE REVIEW}

DOI: $10.15611 /$ pn.2017.478.08

JEL Classification: G32, M41

Streszczenie: Artykuł otwiera serię publikacji poświęconych weryfikacji teorii struktury kapitału w warunkach polskich. Na gruncie przeglądu dotychczasowego dorobku zidentyfikowano i omówiono w nim podstawowe teorie, a także wyodrębniono czynniki mogące mieć wpływ na zmiany w strukturze finansowania przedsiębiorstwa. W efekcie, dla celów dalszych badań sformułowano następującą hipotezę: struktura kapitału przedsiębiorstwa zależy od udziału aktywów trwałych w aktywach ogółem, wielkości i wzrostu przedsiębiorstwa, jego rentowności, płynności i wielkości nieodsetkowej tarczy podatkowej.

Słowa kluczowe: struktura kapitału, koszt kapitału, finansowanie.

Summary: The paper begins a series of publications concerning verification of the capital structure theories in the Polish market conditions. On the basis of the literature review fundamental theories were identified and discussed, as well as factors that may affect the changes in the financing structure of the company. For the purposes of further research the following hypothesis was formulated: the capital structure of the company depends on the level of fixed assets, the size and growth of the company, its profitability, liquidity and size of non-interest tax shield.

Keywords: capital structure, cost of capital, financing. 


\section{Wstęp}

Jednym z kluczowych kierunków decyzji finansowych w każdej organizacji jest poszukiwanie źródeł finansowania. Odpowiednia relacja kapitału własnego i obcego, w szczególności w odniesieniu do struktury aktywów, determinuje szybkość i jakość rozwoju. Kształtowanie owej relacji pozwala menedżerom przedsiębiorstw na regulowanie kosztu kapitału oraz ryzyka finansowego. To z kolei bezpośrednio wiąże się $\mathrm{z}$ osiąganiem podstawowego długoterminowego celu finansowego, czyli maksymalizacji wartości poprzez uzyskiwanie rentowności kapitału wyższej niż koszt jego pozyskania i utrzymania. W literaturze przedmiotu zauważalny jest pogląd, że tzw. optymalna struktura kapitałowa jest niezbędna dla zrównoważonego rozwoju przedsiębiorstwa rozumianego jako realizowanie bieżących aspiracji jego interesariuszy bez naruszania możliwości ich realizowania w przyszłości.

Decyzje prowadzące do optymalizacji struktury kapitału zależą od wielu czynników. Owe czynniki oraz ich siła i kierunek oddziaływania na relację kapitałów własnych i obcych jest przedmiotem badań od kilkudziesięciu lat. Do tej pory sformułowano wiele teorii zwanych teoriami struktury kapitału. Do najbardziej znaczących można zaliczyć: model MM, teorię sygnalizacji, teorię agencji, teorię hierarchii źródeł finansowania oraz statyczną teorię substytucji. Większość wymienionych teorii była poddawana weryfikacji na drodze badań empirycznych. Badania te nie przyniosły jak do tej pory jednoznacznej konfirmacji ani falsyfikacji żadnej z nich. Są zatem dalej prowadzone, na różnych rynkach kapitałowych i dla różnych uwarunkowań sektorowych, z wykorzystaniem bardzo zróżnicowanych metod badawczych. W tenże nurt badań wpisuje się niniejsze opracowanie, którego celem jest identyfikacja czynników mogących mieć wpływ na strukturę finansowania przedsiębiorstw w świetle współczesnych teorii. Artykuł ma charakter przeglądu literatury i otwiera cykl publikacji poświęcony badaniom wpływu poszczególnych czynników na strukturę finansowania polskich przedsiębiorstw, a co za tym idzie: wskazaniu adekwatnej do decyzji ich menedżerów teorii struktury kapitału.

\section{Współczesne teorie struktury kapitału}

Jedną z najstarszych znaczących teorii struktury kapitału jest model MM [Modigliani, Miller 1958]. Przy założeniu funkcjonowania przedsiębiorstwa na doskonałym rynku kapitałowym jego autorzy wykazali, że koszt kapitału, a więc i wartość rynkowa przedsiębiorstwa są niezależne od struktury kapitału. Wraz ze wzrostem udziału tańszego kapitału obcego w finansowaniu rośnie ryzyko, a w konsekwencji żądana przez akcjonariuszy stopa zwrotu z akcji (koszt kapitału własnego). Wartości te wzajemnie się kompensują, przez co średnioważony koszt kapitału nie zmienia się. Pierwotny model MM był modyfikowany poprzez wprowadzanie do modelu wielu różnych wielkości urealniających warunki funkcjonowania przedsiębiorstwa (podatku korporacyjnego, podatków dochodowych akcjonariuszy itp.), nie zmieniło to jednak jego głównych tez. 
W 1976 r. M.C. Jensen i W.H. Meckling [1976] opublikowali koncepcję decyzji finansowych opartą na teorii agencji. Uwzględniała ona konflikty interesów pomiędzy akcjonariuszami i wierzycielami a kierownictwem przedsiębiorstwa. Skutkiem zawierania kontraktów zabezpieczających interesy stron są tzw. koszty agencyjne. Strukturę kapitałową należy ustalać, uwzględniając koszty emisji kapitału własnego oraz koszty emisji i obsługi długu. Założono, że dług jest jednym ze sposobów zmniejszających konflikt. Powoduje on konieczność bieżącej obsługi zobowiązań, przez co zmniejsza się ilość gotówki pozostawionej menedżerom. M.C. Jensen [1986] wskazał także, że wypłata zwiększonych dywidend właścicielom powoduje zmniejszenie gotówki w dyspozycji menedżerów. Podsumowując, poprzez wzrost wysokości dywidend i/lub wykorzystania długu, czyli kształtując strukturę kapitału, można ograniczać tendencje menedżerów do wdrażania nieopłacalnych projektów.

Za autora teorii sygnalizacji uznaje się S.A. Rossa [1977]. Zakłada ona, że tylko kierownictwo posiada dokładne informacje na temat przyszłych strumieni dochodów oraz możliwości inwestycyjnych przedsiębiorstwa. Oznacza to, że ustalane przez rynek ceny akcji nie odzwierciedlają wszystkich istotnych informacji. Dopiero poprzez wybór relacji kapitału własnego i obcego zarząd sygnalizuje otoczeniu posiadaną wiedzę. Większy udział długu w strukturze kapitałowej daje sygnał wysokich przyszłych przepływów pieniężnych zapewniających regulowanie zobowiązań. To z kolei powoduje wzrost zaufania inwestorów, prowadzący do wzrostu cen akcji.

Obserwowane niskie zadłużenie wysoko rentownych przedsiębiorstw dały przesłankę do sformułowania teorii hierarchii źródeł finansowania [Myers 1984; Myers, Majluf 1984]. Według niej przedsiębiorstwa preferują określoną, opartą na selekcji negatywnej, kolejność wyboru źródeł finansowania. Zarządzający znają dokładną wartość aktywów przedsiębiorstwa oraz możliwości jego rozwoju, dlatego wypracowany zysk najchętniej przeznaczają na dalsze finansowanie przedsiębiorstwa. Zewnętrzni inwestorzy posiadają mniejszą wiedzę o przedsiębiorstwie. Zatem z ich punktu widzenia udział w kapitale własnym jest bardziej ryzykowny niż pożyczenie pieniędzy. W związku z tym oczekiwana przez inwestorów premia za ryzyko będzie wyższa w przypadku zakupu akcji niż udzielenia pożyczki. Podsumowując, zarządzający w pierwszej kolejności wybierają finansowanie wewnętrzne, a następnie dług. Emisja akcji wybierana jest jako ostatnia.

Na gruncie dyskusji nad modelem MM ukształtowała się statyczna teoria substytucji. Zakłada ona, że optymalna struktura kapitału wynika z porównania korzyści podatkowych z kosztami trudności finansowych i potencjalnymi kosztami agencji kapitału własnego i długu. Wprowadzenie do modelu MM podatku dochodowego spowodowało pojawienie się korzyści z posiadania długu (odsetkowa tarcza podatkowa). Za koszt długu, który przeciwważył korzyści, uznano ryzyko bankructwa [Hirshleifer 1966]. Pierwszy model oparty na tych założeniach zaproponowali A. Kraus i R.H. Litzenberger [1973]. Udoskonalony przez S.C. Myersa [1984] przewiduje, że przedsiębiorstwo wyznacza docelowy stosunek długu do swojej wartości, a następnie stopniowo przesuwa się w kierunku wyznaczonego celu określanego poprzez wyważenie korzyści z tarczy podatkowej wobec kosztów trudności finansowych (upadłości). 


\section{Czynniki ksztaltujące strukturę kapitału przedsiębiorstw}

Szeroką analizę teorii struktury kapitału przeprowadzili M. Harris i A. Raviv [1991]. W jej ramach zwrócili uwagę na czynniki mogące mieć wpływ na decyzje dotyczące finansowania. Tabela 1 przedstawia najważniejsze z nich z określeniem kierunku oddziaływania. Opierając się na polskich doświadczeniach, podobną listę opracowali A. Cwynar i in. [2015].

Aktywa trwałe stanowią dobre zabezpieczenie zobowiązań oraz w mniejszym stopniu niż aktywa obrotowe narażone są na utratę wartości w przypadku kłopotów finansowych. Z punktu widzenia statycznej teorii substytucji wysoki udział majątku trwałego w aktywach może przekładać się na wzrost finansowania kapitałem obcym. Lepsze zabezpieczenie długu powoduje także zmniejszenie się kosztów jego emisji. A zatem również z punktu widzenia teorii agencji zależność pomiędzy wzrostem aktywów trwałych a długiem jest dodatnia. Odmiennie kształtować się ona powinna według teorii hierarchii źródeł finansowania. Większy poziom aktywów trwałych determinuje mniejszą asymetrię informacji, a to powoduje, że koszt kapitału własnego się obniża.

Tabela 1. Wpływ wybranych czynników na udział długu w finansowaniu przedsiębiorstwa

\begin{tabular}{|l|c|c|c|c|}
\hline \multicolumn{1}{|c|}{ Czynnik/Udział długu } & $\begin{array}{c}\text { Teoria } \\
\text { agencji }\end{array}$ & $\begin{array}{c}\text { Teoria } \\
\text { sygnalizacji }\end{array}$ & $\begin{array}{c}\text { Teoria } \\
\text { hierarchii }\end{array}$ & $\begin{array}{c}\text { Teoria } \\
\text { substytucji }\end{array}$ \\
\hline Aktywa trwałe & + & & - & + \\
\hline Wielkość & + & & $-/+$ & + \\
\hline Wzrost & - & + & + & - \\
\hline Rentowność & + & + & - & + \\
\hline Płynność & & & - & + \\
\hline Nieodsetkowa tarcza podatkowa & + & & - & - \\
\hline
\end{tabular}

+ zależność dodatnia; - zależność ujemna; -/+ zależność nieokreślona

Źródło: opracowanie własne na podstawie [Harris, Raviv 1991; Cwynar i in. 2015].

Czynnikiem, którego wpływ na strukturę kapitału uzasadniają statyczna teoria substytucji i teoria agencji, jest wielkość przedsiębiorstwa. Z punktu widzenia pierwszej teorii istotne jest, że duże przedsiębiorstwa prowadzą bardziej zdywersyfikowaną działalność i ryzyko ich bankructwa jest niższe. Duże firmy działają także dłużej niż mniejsze, są bardziej znane i ze względu na swoją reputację koszty emisji długu są dla nich niższe. To oznacza, że według obu teorii im większe przedsiębiorstwo, tym wyższy udział długu $\mathrm{w}$ jego finansowaniu.

Wielkość przedsiębiorstwa sprzyja również zmniejszeniu kosztów emisji akcji. Dużemu przedsiębiorstwu łatwiej jest wyemitować i zbyć swoje akcje niż małej spółce. $Z$ drugiej strony duże przedsiębiorstwa posiadają więcej aktywów w ujęciu bezwzględnym, co powoduje, że zjawisko selekcji negatywnej nabywców tychże 
akcji jest dla nich bardziej istotne. Oznacza to, że z punktu widzenia teorii hierarchii źródeł finansowania zależność pomiędzy wielkością przedsiębiorstwa a stopniem zadłużenia jest nieokreślona.

Czynnikiem związanym z wielkością jest dynamika wzrostu przedsiębiorstwa. Dynamiczny wzrost przedsiębiorstwa wymaga analogicznego wzrostu finansowania. Zgodnie $\mathrm{z}$ teorią hierarchii źródeł finansowania dług będzie $\mathrm{w}$ tym przypadku bardziej preferowany od emisji akcji. Według teorii sygnalizacji szybszy wzrost przedsiębiorstwa jest pozytywnym sygnałem dla inwestorów i podnosi ceny akcji. Wyższa wycena daje możliwość skorzystania z długu po niższej cenie, przy relatywnie niskim ryzyku bankructwa. Oznacza to dodatnią zależność pomiędzy wzrostem przedsiębiorstwa i długiem dla obu wymienionych teorii.

Z kolei statyczna teoria substytucji oraz teoria agencji wskazują na zależność przeciwną. Według pierwszej z wymienionych, koszty bankructwa będą wyższe w przypadku spółek o szybkim wzroście - spółki takie tracą relatywnie więcej na wartości. Z teorii agencji wynika, że szybko rosnące przedsiębiorstwa finansują bardziej ryzykowne projekty, przez co koszt długu jest dla nich wyższy. Wniosek: im dynamika wzrostu przedsiębiorstwa większa, tym mniejszy udział długu w jego finansowaniu.

Jedną z kluczowych determinant wzrostu przedsiębiorstwa jest rentowność. W myśl teorii hierarchii źródeł finansowania powinna ona sprzyjać samofinansowaniu, a więc ograniczać udział długu w strukturze kapitału. Rentowne przedsiębiorstwa generują duże nadwyżki finansowe, dzięki czemu możliwe jest w większej mierze niż w przypadku przedsiębiorstw deficytowych korzystanie $\mathrm{z}$ wewnętrznych źródeł finansowania. W przypadku pozostałych omówionych teorii zależność między rentownością i udziałem długu w finansowaniu przedsiębiorstwa jest przeciwna. Zgodnie z teorią substytucji rentowne przedsiębiorstwa mają niższe koszty związane z ryzykiem bankructwa oraz bardziej cenią korzyści związane z tarczą podatkową. Według teorii sygnalizacji rentowne przedsiębiorstwo wysyła pozytywne sygnały do wierzycieli, co umożliwia dalszy wzrost zadłużenia. Także teoria agencji za bardziej korzystny dla przedsiębiorstw rentownych uznaje wyższy poziom zadłużenia, który mógłby łagodzić problem nadmiernej wolnej gotówki.

Teoria hierarchii źródeł finansowania wskazuje na płynność finansową jako kolejną zmienną, która ma wpływ na zadłużenia przedsiębiorstwa. Przedsiębiorstwa zdolne do generowania znacznej ilości gotówki korzystają z wewnętrznych źródeł finansowania, unikając wykorzystania długu. Zatem im wyższa płynność, tym mniejszy poziom zadłużenia. $Z$ kolei według teorii substytucji zależność ta będzie dodatnia. Wraz ze wzrostem płynnych aktywów koszt ich sprzedaży maleje. To oznacza niższe ryzyko bankructwa, które umożliwia zwiększenie zadłużenia i korzystanie z tarczy podatkowej.

Z teorii substytucji wynika kolejna determinanta struktury kapitałowej - nieodsetkowa tarcza podatkowa. Jest ona mierzona relacją amortyzacji do poziomu aktywów. Wzrost tej relacji jest substytutem odsetkowej tarczy podatkowej i obniża chęć 
zadłużania się. Podobną zależność można sformułować dla teorii hierarchii źródeł finansowania. Im wyższa amortyzacja, tym większa nadwyżka finansowa, co przekłada się na zwiększone możliwości samofinansowania się przedsiębiorstwa. Dodatnią zależność pomiędzy nieodsetkową tarczą podatkową a długiem można natomiast wywieść z teorii agencji. Zwiększająca się amortyzacja to większy strumień wolnych środków pieniężnych $w$ dyspozycji menedżerów. Naturalną drogą do ograniczenia jego nieracjonalnego wykorzystania przez zarządzających jest zwiększanie długu.

Tabela 2 zawiera zestawienie wybranych badań empirycznych, których wyniki potwierdziły wyżej wymienione zależności.

Tabela 2. Wybrane badania empiryczne weryfikujące determinanty struktury kapitału

\begin{tabular}{|l|l|l|}
\hline \multicolumn{1}{|c|}{ Czynnik/Kierunek wpływu } & \multicolumn{1}{|c|}{ Dodatni } & \multicolumn{1}{c|}{ Ujemny } \\
\hline Aktywa trwałe & $\begin{array}{l}\text { Rajan i Zingales [1995] } \\
\text { Pandey i in. [2000] } \\
\text { Frank i Goyal [2003] } \\
\text { Buferna i in. [2005] }\end{array}$ & $\begin{array}{l}\text { Chittenden i in. [1996] } \\
\text { Huang i Song [2006] }\end{array}$ \\
\hline $\begin{array}{l}\text { Wielkość i wzrost } \\
\text { przedsiębiorstwa } \\
\text { Fhaplinsky i Niehaus [1990] } \\
\text { Huang i Goyal [2003] }\end{array}$ & $\begin{array}{l}\text { Rajan i Zingales [1995] } \\
\text { Barclay i Smith [1996] } \\
\text { Bauer [2004] }\end{array}$ \\
\hline Rentowność & $\begin{array}{l}\text { Um [2001] } \\
\text { Jerzemowska i Hajduk [2015] }\end{array}$ & $\begin{array}{l}\text { Rajan i Zingales [1995] } \\
\text { Huang i Song [2006] } \\
\text { Chojnacka [2012] }\end{array}$ \\
\hline Płynność & $\begin{array}{l}\text { Chaplinsky i Niehaus [1990] } \\
\text { Nejad i Wasiuzzaman [2013] }\end{array}$ & $\begin{array}{l}\text { Nie stwierdzono } \\
\text { Nieodsetkowa tarcza } \\
\text { podatkowa }\end{array}$ \\
$\begin{array}{l}\text { Chaplinsky i Niehaus [1990] } \\
\text { Campbell i Jerzemowska [2001] }\end{array}$ & $\begin{array}{l}\text { Upneja i Dalbor [2001] } \\
\text { Gajdka [2002] } \\
\text { Qian i in. [2007] }\end{array}$ \\
\hline
\end{tabular}

Źródło: opracowanie własne na podstawie [Harris, Raviv 1991; Cwynar i in. 2015].

W literaturze wymienia się także inne zmienne mogące mieć wpływ na strukturę kapitału przedsiębiorstwa: prawdopodobieństwo bankructwa, wydatki na reklamę, nakłady i jakość działań badawczo-rozwojowych, innowacyjność itp. [Barowicz 2014]. Są to jednak czynniki znajdujące uzasadnienie zazwyczaj w jednej z teorii. Nie znalazły także dotychczas wystarczającego potwierdzenia w badaniach empirycznych.

\section{Zakończenie}

W doktrynie nauki finansów funkcjonuje wiele teorii struktury kapitału. Z teorii tych wynika równie wiele czynników kształtujących tę strukturę. Badania empiryczne wskazują na różnokierunkowe oddziaływanie poszczególnych czynników na poziom zadłużenia przedsiębiorstwa. Na podstawie dokonanego przeglądu teorii struk- 
tury kapitału popartego dotychczasowymi badaniami empirycznymi można wywieść następującą hipotezę: struktura kapitału przedsiębiorstw w Polsce zależy od udziału aktywów trwałych w aktywach ogółem, wielkości i wzrostu przedsiębiorstwa, jego rentowności, płynności i wielkości nieodsetkowej tarczy podatkowej.

Próba empirycznej weryfikacji powyższej hipotezy w warunkach polskiego rynku kapitałowego zostanie podjęta w kolejnych publikacjach. Identyfikacja określonej zależności, jej kierunek i siła powinny także pozwolić na przypisanie określonej teorii dla przedsiębiorstw funkcjonujących na różnych rynkach i w różnych sektorach.

\section{Literatura}

Barclay M.J., Smith C.W., 1996, On Financial Architecture: Leverage, Maturity and Priority, Journal of Applied Corporate Finance, vol. 8 (4), s. 4-17.

Barowicz M., 2014, Determinanty struktury kapitałowej przedsiębiorstwa. Podejście empiryczne, Wydawnictwo edu-Libri, Kraków 2014.

Bauer P., 2004, Determinants of Capital Structure: Empirical Evidence from the Czech Republic, Czech Journal of Economics and Finance, vol. 54, s. 2-21.

Buferna F., Bangassa K., Hodgkinson L., 2005, Determinants of Capital Structure: Evidence from Libya, Research Paper Series Management School, University of Liverpool.

Campbell K., Jerzemowska M., 2001, Capital Structure Decisions Made by Companies in a Transitional Economy, [w:] Zarzecki D. (ed.), Financial management objectives - organisation - tools, Fundacja Rozwoju Rachunkowości w Polsce, Warszawa.

Chaplinsky S., Niehaus G., 1990, The Determinants of Inside Ownership and Leverage, University of Michigan Working Paper, Ann Arbor.

Chittenden F., Hall H., Hutchinson P., 1996, Small Firm Growth, Access to Capital Markets and Financial Structure: Review of Issues and Empirical Investigation, Small Business Economics, vol. 8 (1), s. 59-67.

Chojnacka E., 2012, Struktura kapitału spótek akcyjnych w Polsce w świetle teorii hierarchii źródet finansowania, CeDeWu, Warszawa.

Cwynar A., Cwynar W., Dankiewicz R., 2015, Studies of Firm Capital Structure Determinants in Poland: An Integrative Review, e-Finanse, vol. 11, no. 4, s. 1-22.

Frank M.Z., Goyal V.K., 2003, Testing the Pecking Order Theory of Capital Structure, Journal of Financial Economics, no. 67, s. 217-248.

Gajdka J., 2002, Teorie struktury kapitatu i ich aplikacja w warunkach polskich, Wydawnictwo Uniwersytetu Łódzkiego, Łódź.

Harris M., Raviv A., 1991, The Theory of Capital Structure, The Journal of Finance”, vol. 46, no. 1, s. 297-355.

Hirshleifer J., 1966, Investment Decision under Uncertainty: Applications of the State Preference Aproach, Quarterly Journal of Economy, no. 80, s. 252-277.

Huang S.G., Song F.M., 2006, The Determinants of Capital Structure: Evidence from China, China Economic Review, vol. 17, no. 1, s. 14-36.

Jensen M.C., 1986, Agency Costs of Free Cash Flow, Corporate Finance, and Takeovers, The American Economic Review, vol. LXXVI, no. 2, s. 323-329.

Jensen M.C., Meckling W.H., 1976, Theory of the Firm: Managerial Behavior, Agency Costs and Ownership Structure, Journal of Financial Economics, vol. 3, no. 4, s. 305-360. 
Jerzemowska M., Hajduk A., 2015, Wptyw rentowności przedsiębiorstwa na strukturę kapitatu na przykładzie spółek akcyjnych notowanych na Giełdzie Papierów Wartościowych w Warszawie, Zeszyty Naukowe UE w Krakowie, nr 2 (938), s. 45-57.

Kim W.S., Sorensen E.H., 1986, Evidence on the Impact of the Agency Costs of Debt in Corporate Debt Policy, Journal of Financial and Quantitative Analysis, vol. 12, s. 1-16.

Kraus A., Litzenberger R.H., 1973, A State-Preference Model of Optimal Finacial Leverage, The Journal of Finance, vol. 28, issue 4, s. 911-922.

Modigliani F., Miller M.H., 1958, The Cost of Capital, Corporation Finance and Theory of Investment, The American Economic Review, vol. XLVIII, no. 3, s. 261-297.

Myers S.C., 1984, The Capital Structure Puzzle, The Journal of Finance, vol. 39, no. 3, s. 575-592.

Myers S.C., Majluf N.S., 1984, Corporate Financing and Investment Decisions when Firms have Information that Investors do not have, Journal of Financial Economics, no. 13, s. 187-221.

Nejad N.R., Wasiuzzaman S., 2013, The Empirical Analysis of Capital Structure Determinants - Evidence From Malaysia, Engineering and Technology, no. 74, s. 466-474.

Pandey I.M., Ranjit M.K., Chotigeat T., 2000, Capital Structure Choices in an Emerging Capital Market: Case of Thailand, Management and Change, vol. 4, s. 1-32.

Qian Y., Tian Y., Wirjanto T.S, 2007, An Empirical Investigation into the Capital Structure Determinants of publicly listed Chinese Companies: a Static Analysis, University of Zhejiang, Hangzhou China and Waterloo, Canada.

Rajan R.G., Zingales L., 1995, What Do We Know about Capital Structure? Some evidence from International Data, Journal of Finance, vol. 50, s. 1421-1460.

Ross S.A., 1977, The Determination of Financial Structure: The Incentive-Signalling Approach, The Bell Journal of Economics, vol. 8, no. 1, s. 23-40.

Um T., 2001, "Determination of Capital Structure and Prediction of Bankruptcy in Korea", niepublikowana rozprawa doktorska, Cornell University, Ithaca, NY.

Upneja A., Dalbor M., 2001, The Choice of Long-Term Debt in the US Lodging Industry, UNVL Journal of Hospitality, Tourism and Leisure Science, http://hotel.unlv (20.10.2016). 